\title{
Influence of E-Service Quality on Customer Satisfaction \& Word of Mouth in App-based Service Industry: A Case on Pathao, Bangladesh
}

\author{
Rashed Al Karim ${ }^{1 *}$ \\ ${ }^{1}$ School of Business, East Delta University, BANGLADESH \\ *Corresponding Author
}

DOI: https://doi.org/10.30880/jtmb.2020.07.01.004

Received 15 April 2020; Accepted 20 May 2020; Available online 16 June 2020

\begin{abstract}
The intents of the present investigation is to identify the influence of e-service quality on customer satisfaction and word of mouth in app-based service industry from Bangladesh. The existing literature was reviewed to discover the dimensions of e-service which were positively associated to the satisfaction of the customer. Multiple researches also indicated positive association between satisfaction and word of mouth. Data were collected by executing survey using a structured questionnaire. Using convenience sampling technique a total of 186 respondents were selected. SPSS (version 24) and PLS software (version 3) were used to analyses the study. From the findings of the study, it was found that, application design, service fulfillment, and customer service have positive and significant influence on the customer satisfaction while the security \& privacy of the company app has no significant influence on customer satisfaction. Also, customer satisfaction of e-services has significant influence word of mouth. This study contributes to getting an insight into growing technology \& its adaptability.
\end{abstract}

Keywords: E-service, E-service quality, Customer satisfaction, Word of mouth, SmartPLS.

\section{Background of the Study}

Bangladesh's GDP has recently made news for its fast growth by reaching approximately 250 billion in 2017 through multiple sector contribution. Technology is one such sector that is showing promising outcome. There are approximately 140 million mobile phone users in Bangladesh of which almost 90 million has internet access (BTRC, 2018). This clearly indicates the huge amount of opportunities application services can have through internet. Ride sharing app is newly added phenomenon in Bangladesh and getting a good amount of attention. The impact of fbike ride-share is evident in 50\% hike in bike sale in 2017. Due to the increased purchasing power of middle income population the app-based ride sharing is getting popular day by day not only in the capital city of Dhaka, this ride sharing concept is also spreading into the other city of the country promptly (IDLC, 2018). As the importance of online transportation services increases, the service quality of the mobile applications will become a critical issue for survival and success. As all the ride-sharing apps offer almost identical services, the only thing that keeps them apart from each other is their "Quality". While service quality has been widely studied, the e-service measurement in Bangladeshi context is non-existent. There is, thus, a gap in the literature regarding the impact of the dimensions of service quality on satisfaction and word of mouth, especially in the mobile application context in Bangladesh. On the other hand, as ride-sharing service is a sensitive service in our country context because of many security \& privacy issues, customers are skeptical towards it. They rely on word of mouth to choose a service as suggested by multiple studies. The consequence of WOM is crucial for promoting ridesharing services since 
difficulties are there in exploiting the traditional promotional mix elements. Hence, the management of word of mouth circulation is also essential for an e-service provider.

Start-ups are booming as the country experience better educational opportunities and economic growth. But not every startup succeeds. For example, "Joldi" was a Dhaka City based on demand delivery service. The startup used to employ bicycle messengers to deliver goods within the Dhaka city but failed to succeed. Another example is of "Incogmito" which was an anonymous social networking platform that used to allow its users to share thoughts and ideas, make confessions, post problems, ask questions without giving off their identity-decided shut down its operations (Mahbub, 2016). These failures indicate faults in services despite of having such increasing internet user demand. Hence, it is important understanding the e-service quality and its dimensions which are vital for especially web-based companies. That's why, the present study is aiming to determine how the e-service quality can influence the customer satisfaction and the word of mouth in the app-based service industry from Bangladesh? This precise question drove this study to attempt to explore the influence of e-service quality on customer satisfaction and word of mouth in the app-based service industry of Bangladesh.

\section{Literature Review}

\subsection{E-Service}

Saanen, Sol and Verbraeck, (1999) defined e-service (electronic services) as the services that provided to the customers through electronic or virtual platforms. It is also defined as the services that use information and communication technologies (ICTs). Service provider, service receiver and the service delivery channels are the three key elements of eservices. In e-service, internet has considered as the core channel for delivering the e-services however other channels, like cellular phone, call center, public kiosk, telephone, television, are also considered as service delivery channel (Rowley, 2006). The technological expansions differentiate e-services from traditional services in many ways. For instance, ICT or employees are encompassed in the interface of e-service facilitated by the internet, whereas, simply employees are included in the interface of the service encounter. Likewise, distance along with opening and working hours provide constraints to traditional service, but e-services are free from these hurdles. Customers can receive the eservices conveniently via internet or other channels from home or from different places, while this type of services are not possible to offer in the context of traditional service. E-services are more versatile than the location-contracted selfservice as well as in e-service, the ICT functionality can be custom-made providing initialed services (Surjadjaja, Ghosh \& Anthony, 2003). E-service allows service providers to access the greater number of customer across the globe, to expanding the market opportunities, to provides the options to customers for alternative channels, to reducing the barriers of entering to the new markets, to lessening the cost of getting new customers and lastly, to gaining the competitive advantages through enhanced customer satisfaction and increased company image ( $\mathrm{Lu}, 2001)$.

\subsection{E-Service Quality}

As mentioned before, with regards to services, quality has often been interpreted as a subjective perception of customers. The perceived quality of customer service is usually understood as the result of how well the real experiences/performance meet customer expectations and as per more than a few researchers from service sectors (Grönroos, 1983; Parasuraman, Zeithaml and Berry, 1988; Bitner, 1990; Bolton and Drew, 1991), it is known as disconfirmation. Parasuraman, Zeithaml and Berry (1985) conceptualized service quality as the relative perceptual deference between client desires and assessments of administration encounters. Paradigm of disconfirmation acclaims that the quality of service is proper or admirable when the level of performance is higher than the expectations, whereas, the quality of service is either inferior or poor if the performance is below expectations. Marketing communication, word of mouth, image of the company, price of the service, customer demands are the some of the key functional factors in gaging the expected quality of e-services. Henceforth, marketing communication includes advertising, direct mail, promotion of sales, websites, communication of internet, and campaigns of sales, which are under the service firm's control. On the other hand, the service firm can only indirectly control the image and word of mouth factors, and public relations which are mostly a function of the service firm's previous performance. Therefore, Parasuraman, Zeithaml, and Malhotra (2005) and Noorshella, Abdullah, and Nursalihah (2015) established that the quality of e-service is a focal point of assessing the competitive advantage of online companies' long-term retention.

\subsection{E-Service Quality Dimensions}

As prior study stated that e-service is diverse in comparison to traditional services both on characteristics and quality wise, the dimensions also seeks difference. There are multiple conceptual theories proposed to measure the quality of eservice. The newly proposed models were built on the essence of dimensions of traditional service quality. The present study has adopted the dimensions that suggested by Wolfinbarger and Gilly (2003), who identified four e-service quality dimensions which are:

Design: Website design comprises all features of the consumer's website experience containing ease of navigation, the search of information, placing of order, processing of order, quality of information, proper personalization and selection of item (Wolfinbarger \& Gilly, 2003). Website design becomes a crucial factor for users in terms of easy navigation and 
application design attractiveness. Development of an eye-catching website design can significantly affect the preferences of the customers and satisfy the customers using the website.

Fulfillment/reliability: Fulfillment/reliability refers to the perfect display and portrayal of an item or product. So that what customers get is what they thought they requested, as well as to delivery of the proper product within the mentioned time frame alongside suitable payment preferences. It covers each function of a service provider working to deliver the promised service (Wolfinbarger \& Gilly, 2003). Maybe, this is the foremost important dimension of e-service for the reason that it offers the core benefits that a customer is trying to find. Noorshella et al. (2015) specified that transaction ability and mode of payment were identified as influential elements of the e-service quality and the authors also discovered that customers are comfortable with websites that offer many payment method options.

Security/Privacy: Security/privacy relates to online payment security and the privacy of the customer's shared information in the platform. In the majority of studies, fear of insecurity was reported as influencing the usage of virtual services. Privacy, in contrast, refers to the protection of different types of data collected from users during the online interactions with or without the user's knowledge (Wolfinbarger \& Gilly, 2003). Noorshella et al. (2015) said security and privacy are one of the main components of the e-service quality, on top of, are the customers' key concerns when choosing services that improve customers ' trust towards accessing the services.

Customer Service: Customer service ought to be responsive, useful, willing to assist that reacts to client requests rapidly (Wolfinbarger and Gilly, 2003). This dimension is like the responsiveness dimension of traditional service quality which alludes to an organization's capacity and ability to offer brief assistance when customers have questions/issues (Zeithaml et al., 2002). In the online setting, platforms have the advantage to give answers for the preapproached question and likewise to request criticism that makes the customer support progressively proportional. Customer Satisfaction

Kotler, Armstrong, and Opresnik (2017) mentioned that customers are satisfied when they get same quality of products with their expectations. The formulation of satisfaction is expressed in Tse and Wilton's (1988) definition as: the consumer's answer to the assessment of the perceived difference between pre-purchase expectations and actual performance as experienced after the product's consumption. The level of satisfaction is a measure of the difference between assumption and perceived results as per Salim, Rahayu, and Sudjatno (2019). If the goods are far from the standards of the customers that means the customers are disappointed. If the goods meet the standards of the consumers, the consumers are impressed. Then, if the product quality is more than the expectations of the customers, the customer would be happy. The satisfaction of customers will help firms to gain customer remembrance, market share and profit margin (Rust \& Zahorik, 1993). Customer satisfaction is one of the key goals of any company. Organizations realize that it is more profitable to keep existing customers than to have to obtain new ones to replace those lost. Theorists in management and marketing discuss the importance of customer satisfaction for the success of a company (McCollKennedy \& Schneider, 2000; Reichheld \& Sasser, 1990). The cost of acquiring a new customer is ten times higher than the cost of retaining a happy customer (Gitomer, 1998). The message is straightforward as satisfied customers help business to grow, while, dissatisfied customers are hampering the growth of the business (Anderson \& Zemke, 1998; Leland \& Bailey, 1995). Thus, like any other physical asset, business organisation should also consider customer satisfaction as an asset which must be monitored and managed effectually. 1qw

\subsection{Affiliation between E-Service Quality \& Customer Satisfaction}

Othman and Owen (2001) indicated a close correlation between the standard of service and the satisfaction of customers. Strong emphasis is placed in the services literature on the importance of perceptions of service quality and the relation between service quality and customer satisfaction (Cronin \& Taylor, 1992; Taylor \& Baker, 1994). The perceived service quality seems connected with customer satisfaction, where the core dimensions and relatively high quality of service are causal precedents of customer satisfaction (Jamal \& Naser, 2002). Bitner et al. (1994) and Anderson et al. (1994) also point to this relationship by suggesting that improved quality of service will have a significant effect on customer satisfaction. The effects of the measurements of e-service quality on customer satisfaction are also quite obvious. In the context of the website, Wolfinbarger and Gilly (2003) conducted an empirical study and found that website design is a strong predictor for internet retailers of customer quality decisions, satisfaction, and loyalty. Highest effect on overall customer satisfaction was the reliability factor (Arasly et al., 2005). Parasuraman et al. (2005) found that privacy plays an important role in website-related higher-order evaluations of customers. On the other hand, knowing customer needs and improving the service based on receptive feedback increases both consumer quality and confidence (Gummerus et al., 2004).

\subsection{Word of Mouth}

Word-of -mouth (WOM) is characterized as oral, unpremeditated, one to one correspondence regarding a brand, a commodity, an association, or a service between an apparent noncommercial communicator and a beneficiary (Higie, Feick, and Price, 1987). WOM is accepted to have the option to support purchasing decisions by purchasers, just as productive on the grounds as it doesn't require a huge capital (Salim, Rahayu, and Sudjatno, 2019). Ahmadi (2019) characterized word of mouth as a verbal exchange about the highlights of a product or service, or a venture in the general public. Informal exchange plays out a major part in the customer buying choices on the grounds that it gives a channel to shoppers to share their judgments, viewpoints, or ideas (Jansen et al., 2009). Customers who have not bought or experienced any items or 
services, they basically search for WOM source concerning specific products or services as they considered the WOM is reliable and truthful to them (Allsop, Bassett, and Hoskins 2007). WOM can be both customary (individual to individual) and electronic. Hennig-Thurau et al. (2004) depicted electronic WOM as any constructive or adverse explanation made by potential, genuine, or previous customers about an item or organization, which is made accessible to a huge number of individuals and foundations through the Internet. According to Constantinides and Fountain (2007), messages that are communicated publicly through social media enrich the visibility of the market resulting in greater negotiating potential for customers. Electronic resources, for example, email, the Internet, cell phones, texting, and online journals have made imparting data and insights simpler than at any other time. DEL Worldwide (2008) found that $70 \%$ of the shoppers approach online sites to get to items and brands related data and $49 \%$ of them conclude their buying choices depending on the data they have recovered from the social media or various online platforms. (Allsop, Bassett, and Hoskins 2007). Electronic word of mouth is comparatively different in a few ways than the regular word of mouth, for instance, (i) the extension of communication line such as to one-to-many, one to one, or many-to-many (Litvin, Goldsmith, and Pan, 2008); (ii) due to the inclusive accessibility, it increases the numbers of audience of equally positive and negative electronic word-of-mouth (Chan \& Guillet, 2011) (iii) it permits sharing between outsiders while customary word of mouth alludes to suppositions from the known ones; (iv) it can be distributed across a range of channels, some allowing for anonymity (Benckendorff et al., 2014) and finally (v) the perishability of the traditional word of mouth has been overcome by online communication for the reason that it can be gathered and conserved (Goldsmith, 2006). Usually, word of mouth includes both the positive and negative insights where positive one comprises decent commendations from customers or individuals that provide to others regarding any goods or services of any particular brands, while negative one reflects complaints or deleterious recommendations that individuals or consumers provide to others regarding any items or services of any specific brands (Datta, Chowdhury \& Chakraborty 2005; Ahmadinejad, 2019). The advantages of WOM communications will enable the business to grow and evolve positively (Ahmadinejad, 2019).

\subsection{Rapport between Satisfaction \& Word of Mouth}

WOM activities can be beneficial to the company as the consumers are aware of the products (Salim et al., 2019). Many marketers consider positive WOM as one of the oldest forms of marketing communication. When customers are satisfied with a service, they tend to communicate this to nine or ten other people. Upon estimation, it is said that informal "word of mouth" helped to build around 50\% of the American Business. Therefore, lack of customer satisfaction has greater impact on this. When customers are not satisfied from a service, they relay their dissatisfaction to around fifteen and twenty other individuals. Each year, an average American company loses about 15-20\% of its customers (Griffin et al., 1995). According to Murray (1991), customers look for others opinion and experience before availing that service and suggests that customers can reduce their risk of availing bad service through "word of mouth." Accordingly, it is suggested by Berry and Parasuraman (1991) that WOM can be vital for the service providers for their gain. Along with the factors affecting WOM, it was also suggested that satisfaction and desire has been complimenting one another to make recommendations for service providers (e.g. Parasuraman et al., 1988). Also, Lovelock et al. (1996) added that service quality and customer satisfaction enhanced WOM. As proposed by Gremlar and Brown (1996), customers with positive WOM communications are more probable to be loyal as customers. So, when it comes retention and acquisition, WOM may have benefits in both these terms.

\section{Proposed Hypotheses}

Depending on the prior discussion, the proposed hypotheses are:

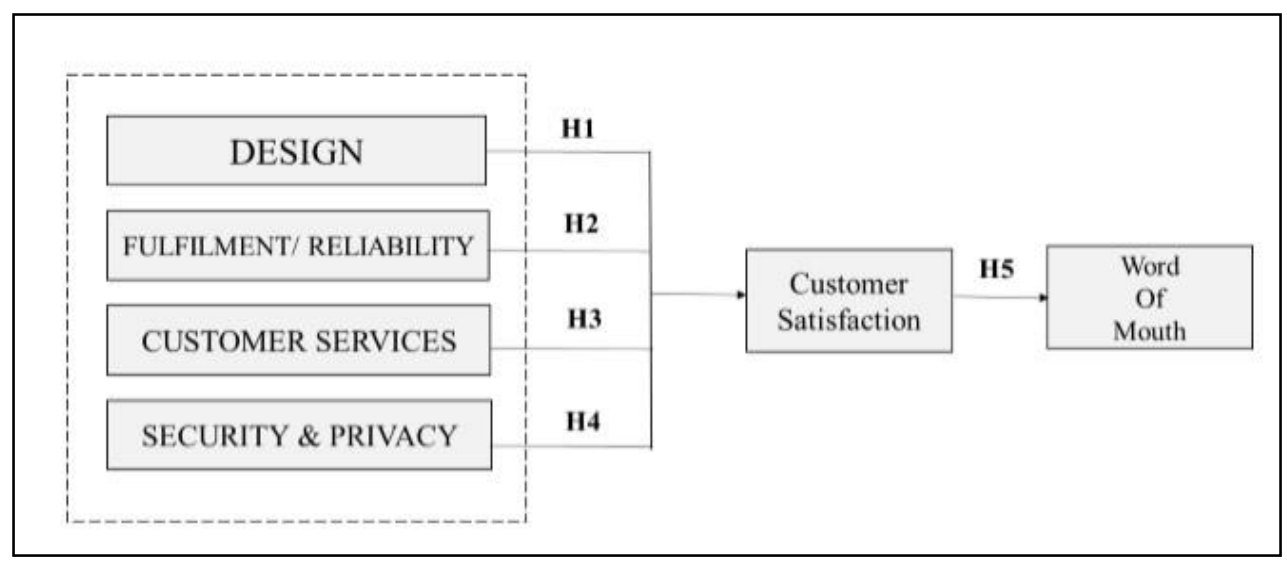


$\mathrm{H}_{2}$ : Service fulfillment of the company positively influences customer satisfaction.

$\mathrm{H}_{3}$ : Customer service of the company positively influences customer satisfaction.

$\mathrm{H}_{4}$ : Security \& privacy of the company app positively influences customer satisfaction. $\mathrm{H}_{5}$ :

Customer satisfaction on e-services positively influences word of mouth.

\section{Methodology}

\section{Questionnaire Design, Sampling Technique \& Sample size}

The questionnaire has three parts. The first part is demographic which involves four questions (Q1 - Q4) on gender, age, education \& profession to understand the respondent's profile. The second part is filtering question that includes two questions (Q5-Q6) to isolate non-users. The third part includes 26 main research questions (Q7-Q31) that were divided into six sections such as Design (Q7-Q11), Fulfillment (Q12-Q18), Customer Service (Q19-Q23), Security \& Privacy (Q24Q26), Satisfaction (Q27), and Word of Mouth (Q28-Q32). To collect primary data, this study has used convenience sampling techniques to attain a decent number of completed questionnaires rapidly and cost efficiently. The population of Chottogram is approximately 4 million (www. populationstat.com). According to Krejcie \& Morgan's (1970), the sample size for more than one million populations should be 384 . However, due to time and resource constraints, collecting information from 384 respondents are difficult. Therefore, by following convenience sampling technique, this study has managed a total of 186 respondents.

\section{Measurement of Variable}

The independent variable of this study is E-service quality which has four dimensions such as design, fulfillment, customer service, and security \& privacy (Table-1). The first dimension design contains five items taken from Fauzi (2018); the second dimension fulfilment has seven items collected from Caruana, (2002) and Wolfinbarger \& Gilly (2003); the third dimension customer service comprises five items adapted from Wolfinbarger \& Gilly (2003); and the fourth dimension security \& privacy has three items modified from Wolfinbarger \& Gilly (2003). The dependent variables of this study are customer satisfaction \& word of mouth. Hence, customer satisfaction is measured by the overall satisfaction of e-service quality. The second dependent variable, word of mouth, is measured through five items, adapted from Eisingerich et al., (2015). All these items were scaled in a five-point Likert scale starting from Strongly Disagree (1), Disagree (2), Neither Agree nor Disagree (3), Agree (4), and Strongly Agree (5)

Table 1 - Measurement of Variables

\begin{tabular}{|c|c|c|c|c|}
\hline Variables & & & Items & Sources \\
\hline \multirow{20}{*}{$\begin{array}{l}\text { E-Service } \\
\text { Quality }\end{array}$} & \multirow{5}{*}{ Design } & DN1 & App layout is visually appealing & \multirow{5}{*}{ Fauzi (2018) } \\
\hline & & DN2 & App is easy to navigate & \\
\hline & & DN3 & Transaction process on the app is easy \& quick & \\
\hline & & DN4 & The application loads quickly. & \\
\hline & & DN5 & Provides organized service category information & \\
\hline & \multirow{7}{*}{ Fulfilment } & FM1 & Ensures accurate services from the very first time & \multirow[t]{2}{*}{ Caruana, (2002) } \\
\hline & & FM2 & Delivers services within promised time & \\
\hline & & FM3 & $\begin{array}{l}\text { Offers variety of products (such as, bike, car and food } \\
\text { service) }\end{array}$ & $\begin{array}{l}\text { Wolfinbarger \& } \\
\text { Gilly (2003) }\end{array}$ \\
\hline & & FM4 & Keeps customers notified about service timeline & \multirow{4}{*}{ Caruana, (2002) } \\
\hline & & FM5 & Provides services $24 / 7$ to the customers & \\
\hline & & FM6 & Provides convenient business hour & \\
\hline & & FM7 & Makes customers feel safe in their transactions & \\
\hline & \multirow{5}{*}{$\begin{array}{l}\text { Customer } \\
\text { Service }\end{array}$} & CS1 & Willing and ready to respond to customer needs. & \multirow{5}{*}{$\begin{array}{l}\text { Wolfinbarger \& } \\
\text { Gilly (2003) }\end{array}$} \\
\hline & & $\mathrm{CS} 2$ & Inquiries are answered promptly. & \\
\hline & & CS3 & Shows a sincere interest in solving customers problems & \\
\hline & & CS4 & $\begin{array}{l}\text { Customer service personnel are always willing to help } \\
\text { customers }\end{array}$ & \\
\hline & & CS5 & Provides customers a pleasant buying experience & \\
\hline & \multirow{3}{*}{$\begin{array}{l}\text { Security \& } \\
\text { Privacy }\end{array}$} & SP1 & Keeps customers personal information safe & \multirow{3}{*}{$\begin{array}{l}\text { Wolfinbarger \& } \\
\text { Gilly (2003) }\end{array}$} \\
\hline & & SP2 & Ensures payment security & \\
\hline & & SP3 & $\begin{array}{l}\text { Ensures customers trust regarding perceived risk (Any } \\
\text { potential risk) }\end{array}$ & \\
\hline
\end{tabular}




\begin{tabular}{llll}
\hline Satisfaction & SAT1 & Satisfied with overall services of the organisation & Fauzi (2018) \\
\hline & WM1 & $\begin{array}{l}\text { I say always positive things about the organisation to } \\
\text { other people }\end{array}$ & Eisingerich et al., \\
\cline { 2 - 3 } $\begin{array}{l}\text { Word of } \\
\text { Mouth }\end{array}$ & WM2 & I recommend the organisation to others in person & I encourage friends and family to use their service \\
\cline { 2 - 3 } & WM4 & $\begin{array}{l}\text { I point out the positive aspects of the organisation if } \\
\text { anybody criticizes }\end{array}$ \\
\hline
\end{tabular}

\section{Findings Descriptive Statistical Analysis}

About 59.7 percent of respondents are male, while female constitutes 40.3 percent. Even though the service seems to be male dominant, the female numbers are very close to the majority. 67.2 percent of the respondents are aged under 25 years while 26.9 percent of the respondents aged between 26-35 years. Next, 1.6 percent of the respondents have secondary educational qualification while 11.3 percent of the respondents have higher secondary educational qualification. 62.9 percent of the respondents are educated to bachelors while 21.5 percent of the respondents are post graduate and 2.7 percent are others. Around 53.8 percent of the respondents were students, followed by 25.8 percent job holders, 5.9 percent Business, 4.3 percent Teachers, 3.8 percent both for housewife \& others (Table 2).

Table 2 - Descriptive Statistical Analysis

\begin{tabular}{|c|c|c|c|c|}
\hline & & Frequency & Percent & Valid Percent \\
\hline \multirow[b]{3}{*}{ Gender } & Male & 111 & 59.7 & 59.7 \\
\hline & Female & 75 & 40.3 & 40.3 \\
\hline & Total & 186 & 100.0 & 100.0 \\
\hline \multirow{6}{*}{ Age } & Under 25 Yrs. & 125 & 67.2 & 67.2 \\
\hline & 26-35 Yrs. & 50 & 26.9 & 26.9 \\
\hline & 36-45 Yrs. & 7 & 3.8 & 3.8 \\
\hline & 46-55 Yrs. & 3 & 1.6 & 1.6 \\
\hline & over 56 Yrs. & 1 & .5 & .5 \\
\hline & Total & 186 & 100.0 & 100.0 \\
\hline \multirow{6}{*}{ Education } & Secondary & 3 & 1.6 & 1.6 \\
\hline & Higher Secondary & 21 & 11.3 & 11.3 \\
\hline & Bachelor & 117 & 62.9 & 62.9 \\
\hline & Post Graduate & 40 & 21.5 & 21.5 \\
\hline & Others & 5 & 2.7 & 2.7 \\
\hline & Total & 186 & 100.0 & 100.0 \\
\hline \multirow{9}{*}{ Profession } & Business & 11 & 5.9 & 5.9 \\
\hline & Housewife & 7 & 3.8 & 3.8 \\
\hline & Job holder & 48 & 25.8 & 25.8 \\
\hline & Others & 7 & 3.8 & 3.8 \\
\hline & Retired & 1 & .5 & .5 \\
\hline & Student & 100 & 53.8 & 53.8 \\
\hline & Teacher & 8 & 4.3 & 4.3 \\
\hline & Unemployed & 4 & 2.2 & 2.2 \\
\hline & Total & 186 & 100.0 & 100.0 \\
\hline
\end{tabular}

\section{Descriptive Analysis of Filtered Questions}

The purpose of the filtered question was to isolate non-users from the population and to understand their reasons behind it. In this study, 11 responses were of non-users of which female users were dominant with 63.6\% (Table-3). The reasons for not using Pathao highlighted that (Table-4), 27.3\% of them never felt the need to use Pathao, while $27.3 \%$ of them depend on other medium. The other reasons include reckless driver, fear of bikes and loyalty to the other competitors. 
Table 3 - Filtered Gender analysis

\begin{tabular}{l|c|c|c}
\hline \multicolumn{4}{c}{ Gender } \\
\hline & Frequency & Percent & Valid Percent \\
\hline Male & 4 & 36.4 & 36.4 \\
\hline Female & 7 & 63.6 & 63.6 \\
\hline Total & 11 & 100.0 & 100.0 \\
\hline
\end{tabular}

Table 4 - The reasons behind not using Pathao Service

\begin{tabular}{cccc}
\hline & Frequency & Percent & Valid Percent \\
\hline I don't feel safe & 2 & 18.2 & 18.2 \\
\hline I use another vehicle mode & 3 & 27.3 & 27.3 \\
\hline Never felt the need. & 3 & 27.3 & 27.3 \\
\hline Reckless drivers & 1 & 9.1 & 9.1 \\
\hline Scared of bikes & 1 & 9.1 & 9.1 \\
\hline Uber is more reliable & 1 & 9.1 & 9.1 \\
\hline Total & 11 & 100.0 & 100.0 \\
\hline
\end{tabular}

\section{Assessment of Measurement Model Indicator Reliability}

In proportion to Hair et al. (2016), the value for individual item loading should be more than 0.70, however, Hulland (1999) offered a cut-off point of 0.4. Similarly, Hair et al., (2016) posited that "indicators with outer loadings between 0.40 and 0.70 should be considered for removal from the scale only when deleting the indicator leads to an increase in the composite reliability or the average variance extracted above the suggested threshold value". Initially, the PLS algorithm was calculated and there were items that loaded not up to the expectation, for example FM1, FM2, FM4 were excluded for having factor loading less than $0.252,0.191$, and 0.397 respectively. CS3 was excluded to fulfill AVE criteria. The poorly loaded items were deleted based on criteria above mentioned. Table- 5 portrays the retained items and their corresponding loadings.

\section{Internal Consistency Reliability}

According to Hair et al. (2016), the value of the composite reliability and the value of the Cronbach's Alpha have to be more than 0.70 . Our findings illustrate that the composite reliability and Cronbach's alpha values are greater than 0.70 as shown in table 5 and thus as per the criteria of Fornell and Larcker (1981), scales using in this study are consistent.

\section{Convergent Validity}

As per table-5, AVE values for all the constructs have met and exceeded the minimum threshold value of 0.5 in agreement with Hair et al. (2016). Hence, the AVE value of two dependent variables Satisfaction (SAT) and Word of Mouth (WOM) are 1.000 and 0.632 while the independent variables Design (DN), Fulfilment (FM), Customer Service (CS), and Security $\&$ Privacy (SP), have satisfactory AVE values of $0.616,0.567,0.559$, and 0.705 respectively.

Table 5 - Construct reliability, Cronbach's Alpha, Composite Reliability \& AVE

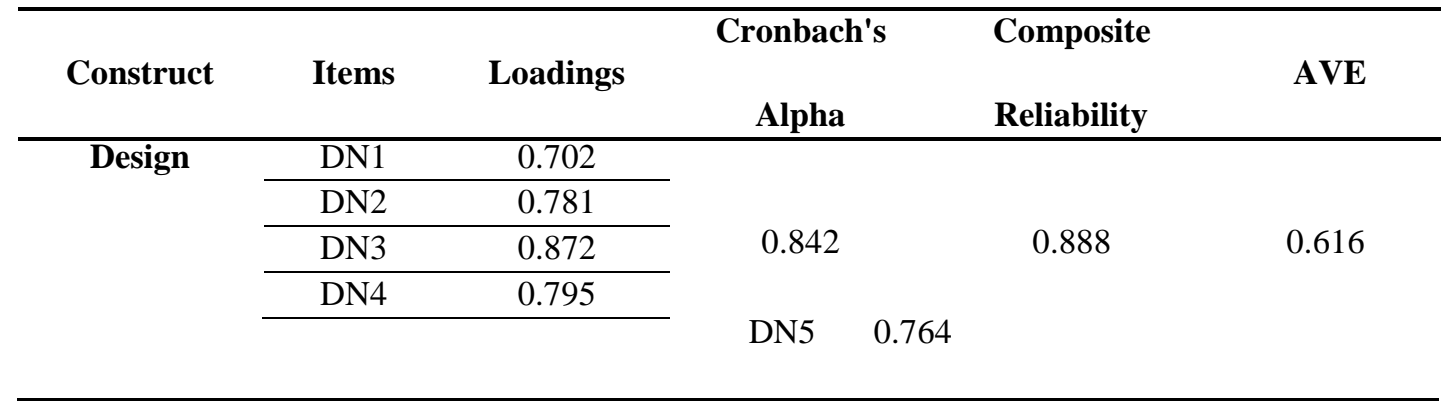

Fulfilment $\quad$ FM3 0.712




\begin{tabular}{|c|c|c|c|}
\hline FM5 & 0.846 & 0.753 & 0.838 \\
\hline FM6 & 0.660 & & \\
\hline
\end{tabular}

\begin{tabular}{|c|c|c|c|c|c|}
\hline \multirow[t]{4}{*}{ Customer } & $\mathrm{CS} 1$ & 0.749 & & \multirow{4}{*}{ Service 0.748} & \multirow{4}{*}{0.8340 .559} \\
\hline & $\mathrm{CS} 2$ & 0.834 & & & \\
\hline & CS4 & 0.704 & & & \\
\hline & CS5 & 0.694 & & & \\
\hline \multirow{3}{*}{$\begin{array}{c}\text { Security } \\
\text { Privacy }\end{array} \quad \&$} & SP1 & 0.843 & \multirow{3}{*}{0.792} & \multirow{3}{*}{0.878} & \multirow{3}{*}{0.705} \\
\hline & SP2 & 0.860 & & & \\
\hline & SP3 & 0.817 & & & \\
\hline Satisfaction & SAT1 & 1.000 & 1.000 & 1.000 & 1.000 \\
\hline \multirow{5}{*}{$\begin{array}{l}\text { Word of } \\
\text { Mouth }\end{array}$} & WOM1 & 0.824 & \multirow{5}{*}{0.854} & \multirow{5}{*}{0.895} & \multirow{5}{*}{0.632} \\
\hline & WOM2 & 0.809 & & & \\
\hline & WOM3 & 0.809 & & & \\
\hline & WOM4 & 0.781 & & & \\
\hline & WOM5 & 0.748 & & & \\
\hline
\end{tabular}

\section{Discriminant Validity}

It expresses how indicators represent the constructs and how they are different from other constructs (Hair et al., 2016). The discriminant validity was calculated based on Fornell and Larcker (1981) criterion where the square root of average variance extracted for a particular construct should be higher than the correlation of the subject construct with any other construct in the model. Table-6 showed that the square root of AVE of each latent variable (the bold diagonal values) is higher than the correlations of the latent variables (the un-bolded diagonal values) and accomplishes Fornell-Larcker's (1981) criterion and signifying the acceptable level of discriminant validity.

Table 6 - Fornell-Larcker Criterion

\begin{tabular}{|c|c|c|c|c|c|c|c|c|}
\hline & CS & DN & FM & SAT & & SP & WOM & AVE \\
\hline $\mathrm{CS}$ & 0.748 & & & & & & & 0.559 \\
\hline $\mathrm{DN}$ & 0.444 & 0.785 & & & & & & 0.616 \\
\hline FM & 0.075 & -0.132 & 0.753 & & & & & 0.567 \\
\hline SAT & 0.372 & 0.465 & -0.189 & 1.000 & & & & 1.000 \\
\hline $\mathrm{SP}$ & 0.637 & 0.529 & -0.028 & & 0.840 & & & 0.705 \\
\hline WOM & 0.645 & 0.793 & -0.077 & 0.554 & & 0.704 & $\begin{array}{l}0.795 \\
\end{array}$ & 0.632 \\
\hline
\end{tabular}

Similarly, the discriminant validity was evaluated by the extent of correlation among the individual items. Table-7 displayed the loadings and cross-loadings of the indicators. Like the latent variable correlation result, the individual items correlation indicated good discriminant validity, as there is no indicator that loaded higher in another construct other than its mother construct. For example, the lowest loading among all the retained indicators is DN1 with 0.702 and DN3 item loaded the highest loading among all the items with 0.872. Based on Chin (1998), Fornell and Larcker (1981) the above suggested the items are more loyal to their mother construct than in any other construct

Table 7 - Cross loading

\begin{tabular}{ccccccc}
\hline & DN & FM & CS & SP & SAT & WOM \\
\hline DN1 & $\mathbf{0 . 7 0 2}$ & -0.175 & 0.252 & 0.378 & 0.328 & 0.530 \\
\hline DN2 & $\mathbf{0 . 7 8 1}$ & -0.244 & 0.356 & 0.385 & 0.364 & 0.602 \\
\hline DN3 & $\mathbf{0 . 8 7 2}$ & -0.131 & 0.370 & 0.433 & 0.394 & 0.724 \\
\hline DN4 & $\mathbf{0 . 7 9 5}$ & 0.006 & 0.409 & 0.452 & 0.394 & 0.629 \\
\hline DN5 & $\mathbf{0 . 7 6 4}$ & 0.019 & 0.344 & 0.423 & 0.339 & 0.614 \\
\hline FM3 & -0.077 & $\mathbf{0 . 7 1 2}$ & 0.055 & -0.007 & -0.159 & -0.003 \\
\hline FN5 & -0.099 & $\mathbf{0 . 8 4 6}$ & 0.010 & -0.050 & -0.174 & -0.092 \\
\hline
\end{tabular}




\begin{tabular}{ccccccc}
\hline FM6 & -0.098 & $\mathbf{0 . 6 6 0}$ & 0.097 & -0.018 & -0.080 & -0.040 \\
\hline FM7 & -0.137 & $\mathbf{0 . 7 8 0}$ & 0.102 & -0.003 & -0.124 & -0.094 \\
\hline CS1 & 0.292 & -0.015 & $\mathbf{0 . 7 4 9}$ & 0.464 & 0.257 & 0.466 \\
\hline CS2 & 0.467 & 0.012 & $\mathbf{0 . 8 3 4}$ & 0.598 & 0.386 & 0.607 \\
\hline CS4 & 0.251 & 0.138 & $\mathbf{0 . 7 0 4}$ & 0.341 & 0.214 & 0.386 \\
\hline CS5 & 0.238 & 0.160 & $\mathbf{0 . 6 9 4}$ & 0.447 & 0.187 & 0.407 \\
\hline SP1 & 0.434 & -0.068 & 0.500 & $\mathbf{0 . 8 4 3}$ & 0.304 & 0.574 \\
\hline SP2 & 0.490 & -0.056 & 0.625 & $\mathbf{0 . 8 6 0}$ & 0.339 & 0.636 \\
\hline SP3 & 0.401 & 0.067 & 0.464 & $\mathbf{0 . 8 1 7}$ & 0.265 & 0.557 \\
\hline SAT1 & 0.465 & -0.189 & 0.372 & 0.363 & $\mathbf{1 . 0 0 0}$ & 0.554 \\
\hline WOM1 & 0.606 & -0.075 & 0.537 & 0.576 & 0.488 & $\mathbf{0 . 8 2 4}$ \\
\hline WOM2 & 0.664 & -0.097 & 0.511 & 0.541 & 0.445 & $\mathbf{0 . 8 0 9}$ \\
\hline WOM3 & 0.671 & -0.163 & 0.420 & 0.451 & 0.458 & $\mathbf{0 . 8 0 9}$ \\
\hline WOM4 & 0.623 & 0.026 & 0.604 & 0.668 & 0.412 & $\mathbf{0 . 7 8 1}$ \\
\hline WOM5 & 0.591 & 0.025 & 0.502 & 0.577 & 0.389 & $\mathbf{0 . 7 4 8}$ \\
\hline
\end{tabular}

\section{Assessment of Structural Model Hypothesis Testing}

Table-9 presented that the result of direct hypotheses and along with Chin, 2010, the t-value should be above 1.645 and $\mathrm{P}$ value should be less than 0.05 at $95 \%$ confident interval. The result supports four out of five hypotheses. Design, fulfillment, customer service has direct positive effect on satisfaction, although, security \& privacy doesn't. Then again, satisfaction (SAT) has direct positive effect on word of mouth (WOM) as per prior literature review.

Table 9 - Result of Direct Hypotheses

\begin{tabular}{lllll}
\hline Hypotheses & Direct Relationship & T-value & P-value & Decision \\
\hline H1 & Design > Satisfaction & 4.040 & 0.000 & supported \\
\hline H2 & Fulfilment > Satisfaction & 2.341 & 0.010 & supported \\
\hline H3 & Customer Service > Satisfaction & 2.240 & 0.013 & supported \\
\hline H4 & Security \&Privacy > Satisfaction & 0.658 & 0.255 & Not supported \\
\hline H5 & Satisfaction > Word of Mouth & 10.236 & 0.000 & supported \\
\hline
\end{tabular}

\section{Assessment of Coefficient of Determination $\left(\mathbf{R}^{\mathbf{2}}\right)$}

According to Falk and Miller (1992), an $\mathrm{R}^{2}$ is considered satisfactorily if it exceeds 1.5 per cent. However, Cohen (1988) and Chin (1998) suggested three levels of structural model quality as substantial (0.26 and 0.67), moderate (0.13 and 0.33$)$ and weak (0.02 and 0.19) respectively. According to table-10, the $\mathrm{R}^{2}$ value of SAT and WOM is respectively 0.277 and 0.307, which are substantial and moderate respectively in line with Cohen (1988) and Chin (1998).

Table 10 - Result of $\mathbf{R}$ Square $\left(\mathbf{R}^{2}\right)$

\section{Effect Size $\left(\mathbf{f}^{\mathbf{2}}\right)$}

\begin{tabular}{lcc}
\hline Dependent Variable & R Square $\left(\mathbf{R}^{\mathbf{2}}\right)$ & R Square Adjusted \\
\hline SAT & 0.277 & 0.261 \\
\hline WOM & 0.307 & 0.303 \\
\hline
\end{tabular}

As Cohen (1988), Henseler and Fassott (2010) suggested that further analysis should be carried out to evaluate the effect size $\left(f^{2}\right)$ of the exogenous variable in the main effect model. Effect sizes are evaluated as small $(0.02)$, medium $(0.15)$ or large (0.35) according to Cohen (1988). Although Chin et al. (2003) posited that even a small effect size should not be neglected. 
Table 11- Result of Effect Size (f' $\left.{ }^{2}\right)$

\begin{tabular}{llcc}
\hline Endogenous Construct & Exogenous Construct & $\boldsymbol{f}$ & Effect Size \\
\hline \multirow{3}{*}{ SAT } & Design & 0.099 & Small \\
\cline { 2 - 4 } & Fulfilment & 0.034 & Small \\
\cline { 2 - 4 } & Customer Service & 0.032 & Small \\
\cline { 2 - 4 } & Security \& Privacy & 0.002 & No effect \\
\hline WOM & Satisfaction & 0.443 & Large \\
\hline
\end{tabular}

Thus, table-11 demonstrated that according to Cohen (1988), design has the biggest effect on satisfaction with 0.099 followed by fulfillment and customer service with respectively $0.034 \& 0.032$ among the exogenous construct. Security \& privacy has almost no effect on satisfaction. On the other hand, satisfaction (SAT) has a largest effect of 0.443 on word of mouth (WOM).

\section{Predictive Relevance $\left(\mathbf{Q}^{2}\right)$}

Apart from examining the degree to which the model explained $\left(\mathrm{R}^{2}\right)$ variance in the depended variable as a condition for predictive accuracy, Hair et al. (2016) recommended that Stone-Geisser's $Q^{2}$ should be used to examine the predictive relevance of a model (Geisser, 1974; Stone, 1974). It is evaluated as having predictive relevance, if the $\mathrm{Q}^{2}$ value for the endogenous latent construct is greater than 0 (Hair et al., 2016). The table-12 illustrated that, there is substantial evidence of predictive relevance, because the value of the $\mathrm{Q}^{2}$ exceeds 0 in line with Hair et al., (2016).

Table 12 - Construct Cross Validated Redundancy

\begin{tabular}{cccc}
\hline & SSO & SSE & Q $^{2}(=1-$ SSE/SSO $)$ \\
\hline SAT & 186.000 & 142.986 & 0.231 \\
\hline WOM & 930.000 & 764.336 & 0.178 \\
\hline
\end{tabular}

\section{Discussion \& General Conclusion}

E-service is the new defining facet of service that offers many advantages over traditional service \& its quality. Eservice offers broader \& greater customer base creating a platform to serve better and gain competitive advantage. Maintaining the quality becomes vital for tech companies especially as the physical evidence is limited in the application or website. Literature review repeatedly discussed the effects of service quality on satisfaction which is an important variable that makes sure customers have a good image of the company and they retain ensuring company profitability. The study also focused on the effect of satisfaction on word of mouth which is another vital part of the whole model. Word of mouth is an obvious consequence of satisfaction supported by multiple authors. The circulation of word of mouth represents the brand image \& satisfaction of the company simultaneously among its customers. So, taking care of word of mouth is the ultimate goal for any company. Hypotheses were proposed based on the literature review for this study. Considering this element in a business, to find out the relationship between e-service quality \& satisfaction of Pathao in Bangladesh and the relationship between satisfaction \& word of mouth, an in-depth analysis was conducted throughout this study.

To find out the result of this study, quantitative research design was used and to collect the primary data structured questionnaire design and convenience sampling technique was applied. A sample size of 186 was collected to evaluate this study and indicators were generated on the basis of a literature review. To assess the reliability and validity, multicollinearity was carried out. SPSS software package was also used to present the data demographically and to convert the data for SmartPLS (version 3) software for factor analysis. Result displays that there is significant positive relationship between e-service quality and satisfaction. E-service includes design, fulfilment, customer service, security \& privacy. These four indicators offered four individual hypotheses. The hypotheses test results indicate that, Pathao users are affected by the app design, service fulfillment \& customer service that influences their satisfaction, whereas the security \& privacy aspect of pathao doesn't affect their satisfaction. On the other hand, there is a significant relationship between satisfaction and word of mouth.

\section{Managerial Implications}

This research targeted to study the effect of e-service quality dimensions on satisfaction and on WOM for Pathao service users in Chittagong. In addition, this study examined the interrelationships among these variables and provided statistical evidence for their significance. Data analysis proposed that, the more accurate service is provided, the more they are satisfied with the service. And the more they are satisfied, the more they are willing to engage in positive word of 
mouth. This is in accordance with prior research findings in the services sector. Considering E- service quality dimensions, "design" \& "fulfilment" appears to be two of the most important variables in the model as it offers the highest effect on satisfaction. Followed by customer service. According to this, users mostly care about the comfort \& usability offering of Pathao app, the ability of fulfilling service need on time in convenient hours supported by payment options, a prompt service to deal with any issue. This finding is important because it highlights the role of this service aspects not only in case of influencing satisfaction but also in the indirect promotion of it, through the effect on the users' intention to recommend the service.

Hence, based on the results, it is recommended that Pathao maintains \& improves its App usability as being able to navigate through $\&$ understanding the process is vital for using the service. Furthermore, Pathao needs to focus on smoother service fulfillment by providing vigorous service variety in all verticals, being available in convenient hours and providing supporting facilities so that it strengthens the satisfaction ultimately effecting the company profitability through retention. As the finding also suggests satisfaction having a very significant effect on word of mouth, Pathao needs to engage with the customers more so that the indirect promotion remains under control. Previous studies show, word of mouth is not something controllable by the company, neither can the negative word of mouth be prevented. But it can be minimized through different channel. Pathao needs to be alert in the social media where people mostly share their opinion. By being active among users, Pathao can utilize its customer service to mitigate any issue fast. It will help to create a good customer perception. Then again, positive word of mouth in social media and traditional channels is common marketing strategy and should be nurtured accordingly for sustainable growth of the organisations as well to survive in the competitive business marketplace.

\section{Limitations \& Scope for Future Study}

One of the key limitations of this study is small sample size which was 186 and may not be representative of the whole population. Thus, further study can be done by increasing sample size to generate more illustrative outcome. Moreover, the present study is based on the second largest city of Bangladesh, i.e. Chattogram, thus further study can be done by gathering data from different cities of Bangladesh to display more accurate and reliable consequences. This study measures e-service quality on the basis of four dimensions such as design, fulfillment, customer service, and security and privacy. Future study may be conduct by exploring more aspects or dimensions of E-service quality. Lastly, future study may cover more consequences of e-service quality and satisfaction such as customer retention, brand image etc.

\section{References}

[1] Ahmadi, A. (2019). Thai Airways: key influencing factors on customers' word of mouth. International Journal of Quality \& Reliability Management, 36(1), 40-57

[2] Ahmadinejad, B. (2019). The Impact of Customer Satisfaction on Word of Mouth Marketing (Case Study: Bamilo Online Store). SCIREA Journal of Management, 3(2), 40-52

[3] Allsop, Dee T., Bryce R. Bassett, and James A. Hoskins. (2007). Word-of-Mouth Research Principles and Applications. Journal of Advertising Research, 47 (4), 398-411

[4] Anderson, K. \& Zemke, R. (1998). Delivering knock your socks off service. New York: AMACOM

[5] Arasly, H., Katircioglu, S.T. and Mehtap-Smadi, S. (2005). A comparison of service quality in the banking industry. International Journal of Bank Marketing, 23(7), 508-26

[6] Benckendorff, Pierre J., Pauline J. Sheldon, and Daniel R. Fesenmaier. (2014). Social Media and Tourism. In Tourism Information Technology, 2nd edition. Oxford: CABI

[7] Berry, L. \& Parasuraman, A. (1991), Marketing Services, The Free Press, New York, NY

[8] Bitner, M.J., Booms, B.H. \& Mohr, L.A. (1994). Critical service encounters: the employees Viewpoint. Journal of Marketing, 58(4), 95-106

[9] Bitner, M-J (1990). Evaluating Service Encounters: The Effects of Physical Surroundings and Employee Responses. Journal of Marketing ,54 (4), 69-82

[10] Bolton, R.N. \& Drew, J. H. (1991). A Multistage Model of Customers' Assessments of Service Quality and Value. Journal of Consumer Research, 17 (3), 375-384

[11] BTRC. (2018). Bangladesh Telecommunication Regulatory Commission (BTRC) Statistics. Retrieved February 17, 2019. from BTRC: http://www.btrc.gov.bd/

[12] Caruana, A. (2002). Service loyalty: The effects of service quality and the mediating role of Customer satisfaction. European journal of marketing, 36(7/8), 811-828

[13] Chan, N. L., \& Guillet, B. D. (2011). Investigation of social media marketing: how does the hotel Industry in Hong Kong perform in marketing on social media websites?. Journal of Travel \& Tourism Marketing, 28(4), $345-$ 368 
[14] Chin, W. W. (1998). The partial least squares approach to structural equation modeling. Modern Methods for business research, 295(2), 295-336

[15] Chin, W. W. (2010). Bootstrap cross-validation indices for PLS path model assessment. In V. E.

[16] Vinzi, W. W. Chin, J. Henseler \& H. Wang (Eds.), Handbook of partial least squares (83-97). Verlag Berlin Heidelberg: Springer

[17] Cohen, J. (1988). Statistical power analysis for the behavioral sciences (2nd ed.). Hillsdale: Lawrence Earlbaum Associates. Chin, W. W. (1998). Commentary: Issues and opinion on Structural equation modeling. MIS quarterly, 22(1), 7-16

[18] Constantinides, E., \& Fountain, S. (2007). Web 2.0: Conceptual foundations and marketing issues. Journal of Direct Data and Digital Marketing Practice, 9(3), 231-244

[19] Cronin, J.J. and Taylor, S.A. (1992). Measuring service quality: a reexamination and extension. Journal of Marketing, 56, 55-68

[20] Datta, P. R., Chowdhury, D. N., \& Chakraborty, B. R. (2005). Viral marketing: New form of word of-mouth through Internet. The business review, 3(2), 69-75

[21] DEI Worldwide, E. (2008). The impact of social media on purchasing behaviour, Engaging Consumers Online. Retrieved 23/03, 2019, from http://www.deiworldwide.com/files/DEIStudy\%20ConsumersOnline-Summary.pdf

[22] Eisingerich, A. B., Chun, H. H., Liu, Y., Jia, H., \& Bell, S. J. (2015). Why recommend a brand face_to _face but not on Facebook? How word _of_ mouth on online social sites differs from traditional word _of _ mouth. Journal of Consumer Psychology, 25(1), 120-128

[23] Falk, R. F. \& Miller, N. B. (1992). A primer for soft modeling. OH, US: University of Akron Press, Akron

[24] Fauzi, A. A. (2018). Electronic service quality on mobile application of online transportation services. Jurnal Manajemen Indonesia, 18(1), 2-14

[25] Fornell, C. \& Larcker, D. F. (1981). Evaluating structural equation models with unobservable variables and measurement error. Journal of marketing research, 18(1), 39-50

[26] Fornell, C., \& Larcker, D. F. (1981). Evaluating structural equation models with unobservable variables and measurement error. Journal of marketing research, 18(1), 39-50

[27] Geisser, S. (1974). A predictive approach to the random effect model. Biometrika, 61(1), 101-107

[28] Gitomer, J. (1998). Customer satisfaction is worthless, customer loyalty is priceless: How to make customers love you, keep them coming back, and tell everyone they know. Austin, TX: Bard Press. Goldsmith, R. E. (2008). Electronic word-of-mouth. In Electronic Commerce: Concepts, Methodologies, Tools, and Applications (pp. $2143-$ 2149). IGI Global

[29] Gremler, D. D., \& Brown, S. W. (1996). Service loyalty: its nature, importance, And implications. Advancing service quality: A global perspective, 5, 171-181

[30] Griffin, A., Gleason, G., Preiss, R., \& Shevenaugh, D. (1995). Best practice for customer satisfaction in manufacturing firms. MIT Sloan Management Review, 36(2), 87

[31] Grönroos, C. (1983). Strategic management and marketing in the service sector. Cambridge, MA: Marketing Science Institute

[32] Gummerus, J., Liljander, V., Pura, M., \& Van Riel, A. (2004). Customer loyalty to content-based web sites: the case of an online health-care service. Journal of services Marketing, 18(3), 175-186

[33] Guo, X., Ling, K. C., \& Liu, M. (2012). Evaluating factors influencing consumer satisfaction towards online shopping in China. Asian Social Science, 8(13), 40-49

[34] Hair Jr, J. F., Hult, G. T. M., Ringle, C., \& Sarstedt, M. (2016). A primer on partial least squares structural equation modeling (PLS-SEM). Sage publications

[35] Hennig-Thurau, T., Gwinner, K. P., Walsh, G., \& Gremler, D. D. (2004). Electronic word-of-mouth via consumeropinion platforms: What motivates consumers to articulate themselves on the Internet. Journal of Interactive Marketing, 18(1), 38-52

[36] Henseler, J., \& Fassott, G. (2010). Testing moderating effects in PLS path models: An illustration of available procedures. In V. E. Vinzi, W. W. Chin, J. Henseler \& H. Wang (Eds.), Handbook of partial least squares (713735). London: Springer

[37] Higie, R. A., Feick, L. F., \& Price, L. L. (1987). Types and amount of word-of- mouth communications about retailers. Journal of Retailing, 63, 260-278

[38] Hulland, J. (1999). Use of partial least squares (PLS) in strategic management research: a review of four recent studies. Strategic management journal, 20(2), 195-204 
[39] IDLC (2018). Ride sharing in Bangladesh- Disrupting the way we commute. IDLC monthly, 14(6), 4-36

[40] Jamal, A. \& Naser, K. (2002). Customer satisfaction and retail banking: an assessment of some of the key antecedents of customer satisfaction in retail banking. International Journal of Bank Marketing, 20(4),146-60

[41] Jansen, B. J., Zhang, M., Sobel, K., \& Chowdury, A. (2009). Twitter power: Tweets as electronic word of Mouth. Journal of the Association Society for Information Science and Technology, 60(11), 2169-2188

[42] Kotler, P., Armstrong, G., and Opresnik, M. O. (2017). Principles of Marketing (17e Global). Harlow: Pearson Education Limited

[43] Krejcie, R. V., \& Morgan, D. W. (1970). Determining sample size for research activities. Educational and psychological measurement, 30(3), 607-610

[44] Lee, G. G., \& Lin, H. F. (2005). Customer perceptions of e-service quality in online shopping. International Journal of Retail \& Distribution Management, 33(2), 161-176

[45] Leland, K., \& Bailey, K. (1995). Customer Service for Dummies. Foster City, CA: IDG Books

[46] Litvin, S. W., Goldsmith, R. E., \& Pan, B. (2008). Electronic word-of-mouth in hospitality and tourism management. Tourism management, 29(3), 458-468

[47] Lovelock, C., Vandermerwe, S. \& Lewis, B. (1996). Services Marketing: A European Perspective. NJ: PrenticeHall, Englewood Cliffs

[48] Lu, J. (2001). Measuring costs/benefits of e-business applications \& customer satisfaction. $2^{\text {nd }}$ International WeB Conference, 1, 139-47

[49] Mahbub, I. (2016). 05 Startups That Failed in Bangladesh Last Year. Future start-up publishers. Retrieved April 04, 2019, from https://futurestartup.com/2016/04/04/05-startups-failed-bangladesh last-year/

[50] McColl-Kennedy, J., \& Schneider, U. (2000). Measuring customer satisfaction: why, what and how. Total Quality Management,11(7), 1-14

[51] Murray, K.B. (1991). A test of services marketing theory: consumer information acquisition activities. Journal of Marketing, 55 (1), 10-25

[52] Noorshella, C. N., Abdullah, A. M., \& Nursalihah, A. R. (2015). Examining the Key Factors Affecting e-Service Quality of Small Online Apparel Businesses in Malaysia. Sage Open, 5(2), 210

[53] Nunnally, J., \& Bernstein, I. (1994). Psychometric Theory (3rd ed.). New York: McGraw-Hill

[54] Othman, A., \& Owen, L. (2001). Adopting and measuring customer service quality (SQ) in Islamic banks: a case study in Kuwait Finance House. International Journal of Islamic Financial Services, 3(1), 1-26

[55] Parasuraman, A., Zeithaml, V. A., \& Malhotra, A. (2005). E-S-QUAL: A Multiple-Item Scale for Assessing Electronic Service Quality. Journal of Service Research, 7, 1-21

[56] Parasuraman, A., Zeithaml, V.A. \& Berry, L.L. (1985). A conceptual model of service quality and its implications for future research. Journal of Marketing,49, 41-50

[57] Parasuraman, A., Zeithaml, V.A. \& Berry, L.L. (1988), SERVQUAL: a multiple-item scale for measuring consumer perceptions of service quality. Journal of Retailing, 64(1), 12-40

[58] Reichheld, F. \& Sasser, W.E., Jr. (1990). Zero defections: Quality comes to services. Boston: Harvard Business Review

[59] Rowley, J. (2006) An analysis of the e-service literature: towards a research agenda. Internet Research, 16(3), 339359

[60] Rust, R. T., \& Zahorik, A. J. (1993). Customer satisfaction, customer retention, and market share. Journal of retailing, 69(2), 193-215

[61] Saanen, Y.A., Sol, H.G \& Verbraeck, A. (1999). Snapshots of e-commerce's opportunities and threats. Electronic Markets, 9(3), 181-189

[62] Salim, T. P., Rahayu, M., \& Sudjatno, S. (2019). Effect of the Service Quality on Tutoring Customer's Word of Mouth and Satisfaction in Malang City. Jurnal Aplikasi Manajemen, 17(3), 522-529

[63] Stone, M. (1974). Cross-validatory choice and assessment of statistical predictions. Journal of the Royal Statistical Society, Series B (Methodological), 36(2), 111-147

[64] Sureshchandar, G. S., Rajendran, C., \& Anantharaman, R. N. (2002). The relationship between service quality and customer satisfaction-a factor specific approach. Journal of services marketing, 16(4), 363-379

[65] Surjadjaja, H., Ghosh, S. \& Antony, J. (2003). Determining and assessing the determinants of e service operations. Managing Service Quality, 13(1), 39-53

[66] Taylor, S.A. \& Baker, T.L. (1994). An assessment of the relationship between service quality and customer satisfaction in the formation of consumers' purchase intentions. Journal of Retailing, 70(2),163-78 
[67] Tse, D. K., \& Wilton, P. C. (1988). Models of consumer satisfaction formation: An extension. Journal of marketing research, 25(2), 204-212. www.populationstat.com/bangladesh/chittagong

[68] Wolfinbarger, M., \& Gilly, M. C. (2003). eTailQ: Dimensionalizing, measuring and predicting etail quality. Journal of Retailing, 79(3), 183-198

[69] Zeithaml, V.A., Parasuraman, A. \& Malhotra, A. (2002). Service quality delivery through websites: a critical review of extant knowledge. Journal of the Academy of Marketing Science, 30(4), 362-75 